Available online at: $\mathrm{http}: / /$ proceeding.rsfpress.com/index.php/pss/index

LPPM UPN “Veteran" Yogyakarta Conference Series

Proceeding on Political and Social Science (PSS)

Volume 1 Number 1 (2020): 257-262

\title{
Increasing Competitiveness of Bakpia SMEs through Improving Business Management and Production Processes
}

\author{
Sutrisno, Dyah Rachmawati L. \\ Universitas Pembangunan Nasional Veteran Yogyakarta \\ Email Address trisno_upnvy@yahoo.co.id
}

\begin{abstract}
UKM Bakpia 803 and UKM Bakpia 19 currently still carry out traditional business management. Currently, UKM Bakpia 803 does not yet have a peeler of mung bean epidermis, so to meet the need for peeled green beans, it is done by buying directly in the market which is expensive. Currently, UKM Bakpia 19 also does not have a representative bakpia roaster, the bakpia roaster that is currently owned has a small capacity. The purpose of this research is to improve business management at UKM Bakpia 803 and UKM Bakpia 803, to create a peeler tool for mung bean epidermis for UKM Bakpia 803, and to make bakpia roaster for UKM Bakpia 19. To improve business management at UKM Bakpia 803 and UKM Bakpia 19 conducted by holding business management training. To realize the mung bean epidermis peeler for UKM Bakpia 803 and the availability of bakpia roasting tools for UKM Bakpia 19 was carried out by designing the construction of a green bean epidermis peeler and a representative bakpia roaster. With the implementation of business management training, the business bookkeeping conducted by UKM Bakpia 803 and UKM Bakpia 19 will be better. With the realization of a representative green bean epidermis peeler and bakpia roaster, it has increased the production capacity and efficiency of bakpia production at UKM Bakpia 803 and UKM Bakpia 19, thereby increasing the business profits obtained.
\end{abstract}

Keywords: Bakpia Roaster, Business Management, Green Bean Epidermis Peeler

\section{INTRODUCTION}

This is an open access article under the CC-BY-NC license.

\section{I.1 Background of The Problem}

At present, UKM Bakpia 803 in carrying out business management is still traditional, where business finances are still combined into one with family finances, so that business profits or losses are not detected properly. Currently, UKM Bakpia 803 also does not have a green bean epidermis peeler, so to meet the need for peeled Hijau beans as raw material for bakpia, it is done by buying in the market which is expensive. As a comparison, the price of peeled 
green beans is Rp.29,000 / kg, while the price of unpeeled green beans is Rp. 18,000 / kg, so the price difference between peeled green beans and unpeeled green beans is quite high, namely Rp.11,000. / kg.Currently, Bakpia 19 UKM in running its business also still applies traditional business management, business finances, and family finances are still mixed into one, so that business profits and losses cannot be detected properly. Currently, UKM Bakpia 19 also does not have a representative bakpia roaster. Bakpia roasting equipment owned by UKM Bakpia 19 is still traditional with small production capacity and without temperature control, so it is not efficient to make bakpia.

To improve business management at UKM Bakpia 803 and UKM Bakpia it is necessary to conduct business training at UKM Bakpia 803 and UKM Bakpia 19. To improve production efficiency and increase production capacity at UKM Bakpia 803 and UKM Bakpia it is necessary to design and build a peanut shell peeler. green and design a representative bakpia grill. With the improvement of business management and production efficiency and increased production capacity, it will increase the competitiveness of Bakpia 803 UKM and Bakpia 19 UKM in competition with similar SMEs.

\section{I.2 Formulation of the problem}

Based on the background of the problems above, the problem raised in this study is how to improve business management and increase the efficiency and production capacity of UKM Bakpia 803 and UKM Bakpia 19?

\section{I.3 Research Purpose}

The purpose of this research is to increase the added value of UKM Bakpia 803 and UKM Bakpia 19 by improving business management and increasing efficiency and production capacity.

\section{LITERATURE REVIEW}

\section{II.1 Business management}

Business management is an effort to regulate everything in running a business so that it can achieve the expected goals. The process of business regulation is important to do so that the business can run smoothly and be able to achieve the targets that have been planned. In addition, by carrying out good business management, you can certainly anticipate various unwanted possibilities in business.

Business management actually has many lines, but in general business management can be divided into four, namely: 1) financial management, which is an activity of planning, budgeting, checking, managing, controlling, seeking, and storing funds owned by an organization or company; 2) human resource management, which is a knowledge of how to regulate the relationship and role of resources (labor) owned by individuals effectively and efficiently and can be used optimally so that the common goal between the company, employees and society is maximized; 3 ) marketing management, which is one of the main activities carried out by a company to maintain the continuity of its company, develop and earn a profit; 4) production management, which is a part of management that has a role in 
coordinating various production activities to achieve goals. (Dharmamesta and Handoko, 1982)

\section{II.2 Mung bean epidermis peeler}

To make the time efficiency of the peeling and the efficiency of the number of workers in the peeling of mung bean epidermis as a raw material in making bakpia, it will be done by making a peeler of mung bean husks. The availability of a mung bean epidermis peeler will shorten the peeling time and maximize the amount of peeled mung bean husk, thus greatly supporting the center to increase the amount of production in order to meet consumer demand. The availability of mung bean epidermis peeler will also increase the efficiency of production costs, because this tool will reduce the number of workers who do the stripping, thereby reducing production costs.

\section{II.3 Bakpia roaster}

The grill is one of the main tools in the bakpia production process. A representative bakpia grill tool will support the bakpia making business to run effectively and efficiently. One of the criteria for a representative bakpia roaster is the availability of a temperature control device, with the presence of a temperature control device it will prevent the bakpia produced from becoming immature or burnt because it is too ripe. In addition, as a means of making food, a representative bakpia grill is made of stainless steel.

\section{II.4 Previous research}

(Qomaruddin, 2015) has conducted research entitled "Design of Green Bean Peeler Machine with Roller System with a capacity of $50 \mathrm{Kg} /$ Hour". The design that has been carried out includes determining the rotation of the roller, the power of the driving motor used, the roller diameter, the size of the pulley, and the type of belt. The results of the design of a mung bean epidermis peeler with a roller system obtained the dimensions and specifications of the machine using a roller diameter of $110 \mathrm{~mm}$ and a shaft of $25 \mathrm{~mm}$, motor power of $0.25 \mathrm{HP}$ with a rotation of 175,262 , and $131 \mathrm{rpm}$. So that a green bean epidermis peeler can be produced with a capacity of $50 \mathrm{~kg} /$ hour.

\section{RESEARCH METHODOLOGY}

The methods and stages in increasing the competitiveness of Bakpia UKM through improved business management and production process improvement are shown in table 1. Direct interviews and observations were conducted to identify the needs of partners, namely UKM Bakpia 803 and UKM Bakpia 19. The training was conducted to improve partner business management. The discussion is applied to the activities of designing tools, operational assistance, manufacturing, and technology dissemination. Observations are applied to the operation test stage. Meanwhile, practice and question and answer methods are carried out at the stages of making, operational assistance, and technology dissemination to partners.

Table 1. Methods and Stages of Increasing Competitiveness of Bakpia SMEs 


\begin{tabular}{|c|c|c|}
\hline No & Activities & Methods \\
\hline 1 & Identify partner needs & Interview and direct observation \\
\hline 2 & $\begin{array}{c}\text { Business management } \\
\text { improvement }\end{array}$ & Training \\
\hline 3 & Design & Discussion \\
\hline 4 & Making & Socialization, practice, and discussion \\
\hline 5 & Operation test & Observation \\
\hline 6 & Operational assistance & $\begin{array}{l}\text { Discussion, practice, and questions and } \\
\text { answers }\end{array}$ \\
\hline 7 & $\begin{array}{l}\text { Technology dissemination to } \\
\text { partners }\end{array}$ & $\begin{array}{l}\text { Discussion, practice, and questions and } \\
\text { answers }\end{array}$ \\
\hline
\end{tabular}

\section{FINDING AND DISCUSSION}

Identification of partner needs was carried out by conducting observations and direct interviews with the head of UKM Bakpia 803 and the chairman of UKM Bakpia 19. Based on the identification results it is known that in running the management business implemented by UKM Bakpia 803 and UKM Bakpia 19 is still traditional. In addition, at this time UKM Bakpia 803 needed a tool for peeling green bean epidermis because currently to meet the needs of peeled green beans, UKM Bakpia 803 did it by buying directly on the market which was expensive. Currently, UKM Bakpia 19 also needs a representative bakpia roaster, because currently the Bakpia roaster that is owned by UKM Bakpia 19 is still simple and has a small capacity.At the stage of business management improvement, business management training was carried out at UKM Bakpia 803 and UKM Bakpia 19. Improvements in business management include financial management, human resource management, production management, and marketing management.

At the design stage, planning for the procurement of appropriate technology tools has been carried out. The appropriate technology tools designed are a representative green bean epidermis peeler and bakpia roaster.At the manufacturing stage, tool specifications are adjusted to the characteristics and needs of partners. In accordance with the characteristics and needs of partners, the specifications of the tool developed are easy to move and the material uses stainless steel because it is used to process food.

During the operational test phase of the mung bean epidermis peeler, representatives from Bakpia 803 were invited to try the tool and provide feedback. At this stage, the representatives of UKM Bakpia 803 were satisfied with the tools that had been made. Specifications for disseminated mung bean epidermis are capacity $3 \mathrm{~kg} /$ minute with a daily average production capacity of $1440 \mathrm{~kg}$, dimensions $30 \mathrm{~cm}$ x $30 \mathrm{~cm}$ x $25 \mathrm{~cm}$, roller diameter $10 \mathrm{~mm}$, number of fins 16 pieces, stainless material steel, the motor uses a $1 / 4$ pk motor, and the function is to peel the epidermis of green beans.

At the bakpia roaster operation stage, representatives of Bakpia 19 UKM were welcome to try the tools and provide feedback. At this stage, the representatives of UKM Bakpia 19 were 
satisfied with the tools made. Specifications for the bakpia roaster that are disseminated are: machine dimensions $1200 \mathrm{~mm} \times 1200 \mathrm{~mm} \times 1600 \mathrm{~mm}$, the tool material is stainless steel/platter with stainless steel product contacts, pan size $600 \mathrm{~mm}$ x $500 \mathrm{~mm}$, number of trays 5, gas stove heating system, equipped with a thermometer, Thermo control, and wheels, with a production capacity of $17 \mathrm{~kg}$ per process.

The test operation of the tool is carried out to foster a sense of trust from SMEs in the usefulness of the disseminated tools. The operation test and demonstration of new tools/machines are also important in reducing the possibility of machine damage due to malpractice so that the existence of new machines/technologies can be of greater benefit to its users (Novita et al., 2019).

Operational assistance has been carried out through training attended by UKM Bakpia 803 and UKM Bakpia 19. The results of the dissemination of appropriate technology tools for peeling mung bean epidermis, namely UKM Bakpia 803 know, understand, and are able to apply green bean processing technology. The application of the mung bean epidermis peeler has increased efficiency in the production cost of bakpia because peeled green beans as raw material for making bakpia, which are usually purchased on the market at a price of $\mathrm{Rp}$. $29,000,-/ \mathrm{kg}$, can be produced by themselves using existing mung bean epidermis peeler. , with the raw form of unpeeled green beans at a price of Rp. 18,000/ kg. The results of the dissemination of a representative bakpia roasting tool, namely Bakpia 19 UKM know, understand, and are able to apply effective and efficient bakpia roasting technology. The application of a representative bakpia roaster has increased the bakpia production capacity. Bakpia roasting process which used to be a simple bakpia roaster with a capacity of $5 \mathrm{~kg}$ for one process, with a representative bakpia roaster can be increased to $17 \mathrm{~kg}$ for one process.

In the application of this technology, one representative green bean epidermis peeler, and one bakpia roaster have been handed over. The management of the mung bean epidermis peeler was handed over to UKM Bakpia 803. Management of representative bakpia roasters was left to UKM Bakpia 19.

\section{CONCLUSION AND FURTHER RESEARCH}

Based on the results and discussion carried out, it can be concluded that the improvement of the competitiveness of Bakpia SMEs has been carried out, one of which is by conducting business management training for UKM Bakpia 803 and UKM Bakpia 19. In addition to increasing the competitiveness of Bakpia UKM, the design of an epidermis peeler has been carried out. which was submitted to UKM Bakpia 803 and the design and construction of a representative bakpia roaster had been carried out which was submitted to UKM Bakpia 19. The availability of green bean epidermis peeler and a representative bakpia roaster has increased production efficiency for UKM Bakpia 803 and increased the production capacity of bakpia for UKM Bakpia 19. 


\section{REFERENCES}

Buchori, A., Setyoadi, Y., Nurdyansyah, F., Ristanto, S., 2020, Diseminasi Teknologi Mesin Pengupas Kulit Ari Kacang Hijau Sistem Roller Terbarukan Di Desa Karangpaing Kecamatan Penawangan Kabupaten Grobogan, Journal Of Dedicators Community, Volume 4, Nomor 2, Jepara

Dharmamesta, Handoko, 1982, Manajemen Pemasaran, Jakarta, Prenhallindo

Kotler, Philip, 2004, Dasar-Dasar Pemasaran Jilid I, Jakarta, Prenhallindo

Novita, M., Buchori, A., \& Mujahidin, A. (2019). Diseminasi Teknologi Mesin Perajang Tembakau Dalam Upaya Menerapkan Ekoteknologi Di Desa Tumbrasanom Kecamatan Kedungadem Kabupaten Bojonegoro. Journal Of Dedicators Community, Volume 3, Nomor 2, Jepara.

Pradana, w., lucitasari, d.r., sutrisno, 2018, analisis ekonomi dan perancangan alat pengupas kulit ari kacang hijau dengan metode vdi 2221, opsi, volume 11, nomor 2, yogyakarta

Qomaruddin, 2015, Rancang Bangun Mesin Pengupas Kulit Ari Kacang Hijau Sistem Roller Kapasitas $50 \mathrm{Kg} / \mathrm{Jam}$, Jurnal SIMETRIS, Vol. 6, No. 2, Kudus

ramadhanti, a.r, bastikarana, r.s, alamsyah, a., widiyanesti, s., 2020, penentuan strategi manajemen hubungan pelanggan dengan analisis kepribadian pelanggan menggunakan pendekatan model ontology, jurnal manajemen indonesia, volume 10, nomor 2, bandung

Sugiharto, A., Nugroho, Y.A., Faritsy, A.Z.A., 2018, Perancangan Dan Implementasi Mesin Pengolah Kumbu Bakpia Berbasis Teknologi Automasi, JTPII, Volume 3, Nomor 2, Surabaya 